\title{
Policy Implementation and The Challenges of Poverty Alleviation in Nigeria
}

\author{
Aminu, Isa \\ Department of Political Science, Federal University Lokoja, Nigeria \\ P.M.B 1154, Lokoja, Kogi State. \\ isaminu2013@gmail.com \\ Onimisi, Timothy \\ Department of Political Science, Federal University Lokoja, Nigeria \\ P.M.B 1154, Lokoja, Kogi State. \\ timothyonimisi@yahoo.com
}

Doi:10.5901/ajis.2014.v3n4p295

\begin{abstract}
The rising profile of poverty in Nigeria has been a source of concern to successive government. To this end, various policies and programmes have been formulated to no avail. Today Nigeria ranked among poorest nations in the world. This is embarrassing considering the enormous wealth of the nation both in human and natural resources. This paper assesses government programmes and policies related to poverty in Nigeria using secondary source of data through content analysis. It was found that the policies and programme have failed to achieve the desired result due to high level of corruption, Top-bottom approach in tackling poverty, inadequate co-ordination of various programmes, politicization of poverty alleviation schemes as well as inconsistency in policies and programmes. It therefore recommended that Anti- corruption Agencies should be streamlined, the adoption of bottom-up approach, de-politicization of empowerment scheme as well as continuity, consistency and commitment for effective implementation.
\end{abstract}

Keywords: Poverty, Poverty Alleviation; Policy Implementation

\section{Introduction}

Worried by the continued rise in poverty level, successively government in Nigeria have not relented in formulating one policy or the other in order to tame this social malaise. But, the poverty level has continued to rise. The sorry state of poverty in Nigeria has led the World Bank (1996) to describe Nigeria as a paradox. This is because Nigeria is a country of immense wealth endowed with human and material resources, yet her citizens continue to wallow in abject poverty. By 1999, the World Bank estimated that Nigeria has earned \$300 billion from oil. Between1999 and 2011, the country netted nearly $\$ 300$ billion in oil and gas. In spite of growth indications as a result of these inflows over the years, Nigeria currently ranked among the poorest countries in the world (World Bank, 2010). Available records indicate that poverty level among Nigerian's population has risen from 17.1 million in 1980 to 112.47 million in 2010 an increase of over $55.7 \%$ Sokoto and Niger State top the list of poorest state in Nigeria with a records of other 71.5 percent of poverty rate, and Northwest and the Northeast records $77.7 \%$ and $76.3 \%$ respectively. While the South West has the least poverty level of $59.10 \%$ on a whole, the poverty level average $70 \%$ of the population (NBS, 2010).

Various Programmes and schemes have been initiated by successive government in Nigeria to tame this social malaise without success as records indicate that poverty has continue to rise unabated. This paper therefore seeks to appraise these policies with a view of proffering solution to meet these challenges of government in Nigeria.

\section{Conceptual Clarification}

There is no universally accepted definition of poverty. Thus, Idakwoji (2002) is of the view that poverty is a multidimensional phenomenon covering economic, social and political dimension. From economic perspective, it implies materials deprivation leading to low income, lack of basic necessities of life. From the social view point, poverty manifest in terms of social inferiority, low status, lack of dignity, insanity, vulnerability and social marginalization. Politically, poverty is manifested in lack of political power, form decision- making and denial of basic natural and political input (Idakwoji, 
2002).

Baratz and Grisgby (1972) defined poverty as a condition involving some deprivations and adverse occurrences that are closely but necessarily exclusively associated with inadequate economic resources. Edozien (1975) Limits his own definition to mean "inadequacy of income to support a minimum standard of living" this definition is narrow considering the multi- dimensional nature of poverty.

A distinction between absolute and relative poverty will not be out of place at this point. Absolute poverty, according to Webster (1993) described situation in which people barely exist, when the next meal may literally be a matter of life or death as the cumulative effects of malnutrition and starvation enfeeble all, particularly children, whose weakness gives them the tragic distinction of having the highest mortality rate for any group in the world. Thus Khalid (2002) is of the view that in these circumstances poverty takes on an "absolute" status since there is nothing beyond it except death.

Relative poverty on the other hand cannot be easily established as an objective concept. Its definition varies among official government agencies and academics. For example, Webster (1993) reported that in 1973. A representative of the National Welfare Rights Organization in the United States estimated that a family of four needed $\$ 7200$ per year to satisfy their basic requirements. Below this, the organization considered people to be in poverty. The US government however, estimated the poverty line for a similar household at an income below $\$ 4500$ (Khalid, 2002).

Townsend (1979) opines that:

Individual, families and groups in the population can be said to be in poverty

when they lack the resources to obtain the types of diet, participate in the activities and have the living conditions and amenities which are customary or at least, widely encourage or approved, in the societies in which they

belong. Their resources are so seriously below those commanded by the average individuals or family that they are in effect, excluded from ordinary living partners, customs and activities".

Implementation is the carrying out, accomplishing, fulfilling, producing or completing a given task (Narendara, 2010). Pressman and Wildavsky (1973), defines it in terms of a relationship to policy as laid down in official documents. They viewed policy implementation as a process of interaction between the setting of goals and actions geared to achieve them.

Policy implementation is the connection between the expression of governmental intention and actual result (O'Toole et.al 1995). Mazmanian and Sabaties (1983:21), defined policy implementation as the carrying out of a basic policy decision, usually incorporated in statute, but which can also take the form of important executive orders or court decisions. Hence, policy implementation involves putting adopted policies into effect successful implementation is dependent upon three elements, policies must be passed down from the executive to the appropriate agency within the government bureaucracy; legislative intent must be translated into operating rules and guidelines; and the dedication of resources to implement the policy under the first element must be joined with co-ordination of the policy with ongoing operations. Policy implementation is a stage of policy-making between the establishment of a policy and the consequences of the policy for the people whom it affects. Implantation involves translating the goals and objectives of policy into an operating on going programme.

Poverty Alleviation Programme was an interim measure put in place in 2000 to address the problem of rising unemployment in the society and to increase the productiveness of the economy (Anger, 2010:141). It was designed to coordinate and monitor poverty alleviation effort and ensure that Nigerians were provided with steady sources of income, high purchasing power, equality education, water, healthcare and housing, stable and affordable power supply, among other (Anger, 2010:142). However, due to lack of coordination and commitment, lack of continuity, improper appreciation of the roots and magnitude of the problem, poor funding of the programmes, policy inconsistency, deficient infrastructural facilities and corruption, these remains the major set back of the fight against poverty alleviation (Mno, 2007).

\section{Overview and Appraisal of Pervious Poverty Eradication Programmes and Policies in Nigeria}

Obadan (2001), argued that all efforts at poverty alleviation in Nigeria were essentially ad-hoc until the inauguration of a poverty alleviation programme Development by the government in 1994. Poverty alleviation progarmmes and strategies were not integrated into the nation's overall development objectives. A closer look at the various National Development plans from 1962-1985, and National Rolling Plans from 1990 indicates that they provided much of the framework for the pursuit of development objectives since the attainment of political Independence in 1960 (Obadan, 2001) However within the framework of the National Development a positive relationship in presumed to exist between growth in the GDP and 
increased welfare for the general citizenry. In the opinion of Obadan (2001) the approach to poverty alleviation as expressed in the fundamental objectives of the development plans did not involve policies and programmes which directly targeted the poor. As a result of this development, the poor were worse off even though the economy has continue to witness increase in growth rate. Obadan (2001) notes in particular that the Structural Adjustment Programme (SAP) introduce in 1986 aggravated the incidence of poverty among many vulnerable groups in the society. As a result of this, several poverty Alleviation Programme Development Committee (PAPDC) in 1994 under the aegis of the National Planning commission. The primary objective of PAPDC was to advise the government on the design, co-ordination and implementation of poverty alleviation programme. This was followed with the establishment of community Action Programme for poverty Alleviation CAPPA in 1996. CAPPA attempts to ensure that the poor are not only carried along in the design and implementation of poverty projects that affects them but also involve in the formulation and management of the poverty projects. Obadan (2001) enumerated the following as some of the factors that have contributed to the failure of poverty related programmes and efforts. They are:

* Lack of targeting mechanisms for the poor and the fact that most of the programmes do not focus directly on the poor.

* Political and policy instability have resulted in frequent policy changes and inconsistent implementation which in turn have prevented continuous progress.

* Inadequate coordination of the various programmes has resulted in each institution carrying out its own activities with resultant duplication of effort and inefficient use of limited resources. Overlapping functions ultimately led to institutional rivalry and conflicts.

* Severe budgetary, management and governance problems have afflicted most of the programmes, resulting in facilities not being completed broken down and abandoned, unstaffed and equipped.

* Lack of accountability and transparency thereby making a programmes to serve as conduit pipes for draining national resources.

* Overextended scope of activities of most institution, resulting in resources being spread too thinly on too many activities. Examples are DFRRI and Better Life Programmes which covered almost every sector and overlapped with many other existing programmes.

* Inappropriate programme design reflecting lack of invovlvvement of beneficiaries in the formulation and implementation of programmes. Consequentlt,beneficiaries were not motivated to identify themselves sufficiently with the successful implementation of the programmes.

* Absence of target setting for ministries, Agencies and programmes.

* Absence of effective collaboration and complementation among the tiers of government.

* Absence of agreed poverty reduction agenda that can be used by all concerned-federalGovernment, state Government, local governments. NGOS, and the international Donor community.

* Most of the programmes lacked mechanisms for their sustainability.

The various policies and programmes initiated by the government between 1986 and 2004 includes: Directorate of Food,Roads and Rural Infrastructure(DFFRI); Better Life Programme (BLP); National Directorate of Employment (NDE); People's Bank of Nigeria(PBN); Community Bank (CB); Family Support Programme (FSP); Family Economic Advancement programme(FEAP); Poverty Eradication Programme (PEP) and The National Poverty Eradication Programme (NAPEP) (Gberevie et al,2010).

Echoing similar view, Yakubu \& Aderunmu (2010) were of the view that the management of poverty eradication programme was worsened by the adoption of a top button approach in the implementation of the policy. The target groups who are the poor in the society living predominantly in the country side, were hardly reached due to the fact that the programme existed at the state and local government headquarters, but failed to have linkage with one traditional community leaders for effective penetration of the grassroots(Eze,2003).

Due to the past failures of poverty eradication programme in Nigeria the National Economic Empowerment and Development strategy NEEDS was conceived at the National Level, SEEDS at the state level and LEEDS at the local Government levels. This is to ensure a holistic approach to addressing a wide range of socio-economic and political issues in the country most especially in the rural areas by reforming government institutions, developing the private sectors, implementation of social charters and value orientation (Yakubu and Aderonmu, 2010).

The Yar'Adua administration came up with an economic reform programmed christened "The Seven Points Agenda". The areas of priority of the agenda are: security of life and property; wealth creation; development of human capital, in particular education; land reform transportation; power and energy and food security. Laudable as this programmes appears, it fails to address the problem of poverty in the country. Lack of political coupled with the fragile 
health of the president combine to ensure the failure of the Yar'Adua administration. The administration retain some of the old programmes of its predecessor such as NDE, NAPEP, NEEDS among others without any clear vision of a different and much better future for Nigerians.

\section{Current Effort to Eradicate Poverty in Nigeria}

Concerned about the rising spate of poverty in the country, President Goodluck Jonathan came up with the Transformation Agenda. The Transformation Agenda is a road map between 2011 and 2015 which is the duration of the present administration and it is necessitated by the need to correct the flaws in the country's drive for development where there is of long term perspective and lack continuity, consistency and commitment (3cs) to agreed policies. The absence of the $3 \mathrm{cs}$, it is agued has as result in the overall welfare of Nigerian citizens. (Usigbe, 2011).

It is further agued that the disregards for these 3cs have resulted in rising unemployment, inequality and poverty. The Transformation Agenda is therefore seen as a holistic strategy that gives cognizance to these $3 \mathrm{cs}$.

The transformation agenda draws its inspiration from the vision 20:2020 and the first National implementation plan (NIP). The agenda is based on a set of priority policy and programme which, when implemented, would transform the Nigerian economy to meet the reform needs of the people. A growth rate of GDP of 11.7 percent is envisaged during the term frame of the programme expected to translate to N73.2 trillion at the end of year 2015. A total investment sum of N40.75 trillion with public sector expected to contribute 60 percent, while the remaining $40 \%$ is expected from the private sector.

The key policies to be pursued by government during the programme period are as follows:

(i) Macro - economic framework and economic direction by;

a. Ensuring greater harmony between fiscal and monetary policy

b. Fiscal prudence to contain inflation at single digit

c. Upward review of revenue allocation formula to the lower tiers of government in the spirit of balanced fiscal federation.

(i) Job creation through vocational training

(ii) Public expenditure management by entrenching a culture of accountability through sanctioning and prosecuting of officers that breach established financial management rules and regulations.

(iii) Good governance through more effective and efficient use of public resources, proper financial management and fiscal prudence.

(iv) Justice and judiciary by ensuring greater independence for the judiciary, eliminating of all forms of corruption in the administration of justice in Nigeria.

(v) Education through the promotion of primary enrolment of all children of school- going age, provision of infrastructure and training of teachers.

(vi) Labour and productivity through creation of five million jobs annually within the next three (3) years, establishment of more skills acquisition centres, implementation of local content policy in all the sectors, especially in the oil and gas industry in order to boost job creation in the country.

(vii) Infrastructure policies, programmes and projects by investing an estimate of N1.896 trillion in the power sector with a view of deregulating the sector to attract foreign investment. Also the proposed investment in the information and communication technology (ITC) sector is estimated at N22.2 billion. The Niger Delta is expected to gulp a whopping sum of N335.05 billion. This is to ensure peace and stability in order to drive sustainable socio-economic development in the area with the aim of reducing the high incidence of poverty, unemployment and insecurity.

(viii) Transportation sector is expected to gulp N4.465billion.The investment in this area would cover roads,rail ways,inland water ways,ports and airports development. the transformation agenda key priority projects are derived from twenty(20)ministries, department and agencies(MDAS)and sectors where a total of 1,613 projects were identified, out of which 385 are new while 1,361 are ongoing(Usigbe,2011).

\section{Conclusion and Recommendatios}

A closer look at the policy framework will suggest that Nigeria should indeed bid for farewell to poverty. However, available statics have continued to indicate rising profiles in poverty level. For instance, the National bureau of statistics reports indicates that poverty has risen from $54.4 \%$ in 2004 to $69 \%$ in 2010. Also, Nigeria's population living within the 
poverty level also rises $7.1 \mathrm{~m}$ in 1980 to $112.47 \mathrm{~m}$ in the year 2010 and increase of $55.7 \%$. Sokoto State has the highest poverty rate of $86.4 \%$. In effect, the North West and the North East accounts for $77.7 \%$ and $76.3 \%$ of poverty rate respectively. The situation has led Richard Hamilton (2012) to conclude that poverty is responsible for the insurgency of Boko Haram in the Northern part of Nigeria. In spite of fact that Nigeria being ranked as the biggest oil producer in Africa and the sixth largest oil producers in the world.

Given the past failures of effort to alleviating poverty in Nigeria, the following recommendations are offered on the way forward for effective implementation.

\subsection{Streamlining of Anti-corruption Agencies:}

Due to the concern about the high level of corruption in the country various Anti-corruption Agencies have been set up to tame this scourge. They include the independent Corrupt Practices and Other Related Offences Commission (ICPC), The Economic and Financial Crimes Commission, (EFCC), the Code of Conduct Bureau (CBC) amongst others. This research will align itself with the recommendation of Orosanye (2012) committee report which recommended the streamlining of these agencies for effective co-ordination and cost effectiveness. Also, there is a need for amendment of the Anti-corruption law to ensure independent from Executive interference. Government efforts at alleviating poverty has failed due to corruption of officials entrusted with the funds.

\subsection{Bottom-Top Approach to poverty alleviation:}

Past effort at alleviating poverty does not involve the people in their planning and implementation. It is therefore necessary to include the direct beneficiaries in the project identification. This will go a long way in promoting empowerment and project management as well as its sustainability.

\subsection{De-politization of Empowerment Scheme}

Obadan (2001) observed that political differences will be a strong factor in the accentuation of poverty in particular areas. This arises when relevant schemes and programmes are resisted in some region/Zone or states simply because of the perceived advantages the implementation could confer on some political parties. Some states government in opposition party usually rejects federal government package for of scoring some political against. The All progressive of Congress (APC) for instance is always opposed to the ruling people Democratic Party (PDP) Policies, even when these packages are given, only card-carrying members of ruling parties are considered. This does not augur for the country.

\subsection{Continuity, consistency and commitment (3sc)}

Past efforts all alleviating poverty has not succeeded because of inconsistency in governmental policies. This has to do mainly with political instability in our polity. However, since the inception of the fourth Republic Nigeria has witnessed a stable political environment with the ruling PDP at the helm of affairs at the federal level. One will have expected the policy of government at the federal level on poverty will remain consistence. Unfortunately, this has not been so. Obasanjo came up with NEEDS, Yar'Adua with Seven points Agenda and now we have Transformation Agenda, YOUWIN and SURE-P. This does not urge well for continuity, consistency and commitment.

By and large, for Nigeria to get out of the present poverty level there is need for government to be more committed, transparent and muster the political will to implement its policies to the latter. This will no doubt help in tacking her challenges as well as ensuring National Security and Development.

\section{References}

Anger, B. (2000) Poverty Eradication, Millennium Development Goals and Sustainable Development in Nigeria. Journal of Sustainable Development

Vol. 3 No. 4 pp 138-141

Baratz, N.S and W.G. Grisby (1972), Thought on Poverty and Its Implementation. Journal of Social Policy, Vol. 6. April.

Edozie, E. O. (1975), Poverty: Some Issues In Concept and Theory" In Rural Poverty In Nigeria. www.gamji.com/article 6000/NEWS 6036.htm Retrived on 02/02/2014.

El-Rufai, N.(2011),The Nemesis Called Oil and Gas". http://saharareporters.com/article/nemesis- called-oil-and-gas-1-nasir-ahmad-el- 
rufai_Retrieved on 24/04/2014

Gberevbie, A. (2007) Poverty Alleviation in Nigeria; Which Way Forwar? Sist.cirad.fr/.../020181NIGERIA_Nationa I_resources_not_on_the_interne._Retrieved on 02/03/2014

Hamilton, R. (2012) Nigerian Living in Poverty Rises to 61\%. http://www.bbc.com/news/world-africa-17015873 Retrieved on 24/04/2014 Idakwoji, P.S. (2002), Introduction To Community Development. www caritasuni.edu.ng/pro/management/pa12.doc Retrieved on $02 / 02 / 2014$

Khalid, S. (2002), The Politics Of Poverty Eradication In Nigeria. http:// www.gamji.com/article6000/NEWS6036.htm

Mazmanian, D.A. and Sabatier, P.A. (1983), Implementation and Public Policy. Glenview, III.: Scott, Foresman

Mno, I. (2007) Poverty: The Challenges, The Imperatives, Zenith Economic Quarterly. 2 (12)

Narendra R. P. (2010) A Critical Account of Policy Implementation Theories: Status and Reconsideration. Nepalese Journal of Public Policy and Governance, Vol. xxv, No.2

National Bureau of Statistics, (2010). The Maiden Press Briefing, Held at the Conference Room, $5^{\text {th }}$ Floor, NBS Headquarters Abuja $25^{\text {th }}$ January

Obadan .M.I. (2001), Poverty Reduction In Nigeria, The Way Forward. http://mustaphamuktar.blogspot.com/2011/01/poverty-alleviationas-machinery-for.html

Osayande P. (2012), Police Reform in Nigeria. www.noprin.org/CSO\%20Panel\%20Final\%20Report.pdf. Retrieved on 25/03/2014

O'Toole, L.J.R. Jr. (1995), "Rational Choice and Policy Implementation", American Review of Public Administration 25 (1) 43-57pp.

Oronsaye, S. (2012), Implementing Orosanye Report. http//www.punchng.com/politics/implementing-the-oronsaye-report Retrieved 24/04/2014

Pressman, J. L. and Wildavsky, A. (1984), Implementation: 3r edn. Bekeley: University of California Press.

Townsend, P. (1979), Poverty in United Kingdom, London: Mac Millaian.

World Bank: (1996) Human development Report, http://www.worldbank.org/en/country/nigeria/overview Retrieved on $22^{\text {nd }}$ April, 2014

World Bank: (2010) Human development Report. http://nigeriapoliticsonline.com/ poverty-has-increased-considerably-in-nigeria-worldbank-as-bureau-of-statistic s- confirms-112-million-nigerians-living-below-poverty-line/ Retrieved on 22 nd April, 2014

Webster, A.(1993), Introduction to Sociology of Development, Hong Kong: the Ma Millian Press.

Yakubu O. D. and Aderonmu, J.A. (2010), Rural Poverty Alleviation and Democracy In Nigeria's fourth Republic (1999-2009). In Journal of Social Sciences 2 (3), 191-195 